\title{
Tinjauan Yuridis Pertahanan Negara Yang Dilakukan Tentara Nasional Indonesia
}

\author{
Heru Drajat Sulistyo \\ Fakultas Hukum, Universitas Soerjo, Jl. Сери KM. 3, Ngawi, 63217 \\ E-mail: herudrajatsulistyo1966@gmail.com
}

\begin{abstract}
In The division of tasks and authority in carrying out national defense and security between the Indonesian National Army (TNI) and the Indonesian National Police (POLRI) has been regulated in the 1945 Constitution. The problems in this study are: how is the national defense carried out by the Indonesian National Army in the Indonesian State Administration System and how is the relationship between the Indonesian National Army and the Indonesian National Police implementing the National Defense in the Indonesian State Administration System. The research method used is a normative legal research method and uses secondary data types. The results of the research study, namely: 1) the main task of the Indonesian National Army is to uphold state sovereignty, maintain the territorial integrity of the Unitary State of the Republic of Indonesia based on the Pancasila and the 1945 Constitution of the Republic of Indonesia, and protect the entire nation and the whole of Indonesia's blood spilled from threats and disturbance to the integrity of the nation and state (Article 7 paragraph (1) of Law No. 34 of 2004 concerning the Indonesian National Army) 2) Operational duties other than war carried out by the Indonesian National Army to assist the Indonesian National Police in the framework of security and public order. 3) The defense sector which is the duty of the Indonesian National Army and the security sector which is the duty of the Indonesian National Police cannot be separated.
\end{abstract}

Keywords — : Indonesian National Army; Indonesian National Police; National Defense.

\section{PENDAHULUAN}

\section{A. Latar Belakang}

Di era ledakan informasi melalui teknologi informasi dan kommunikasi dengan sarana internet informasi dan identitas diri sangat mudah, dapat diperoleh baik untuk kepentingan pemilik data pribadi maupun kepentingan bisnis. Undang-Undang Nomor 11 Tahun 2008 tentang Informasi dan Transaksi Elektronik telah diubah dengan Undang-Undang Nomor 19 Tahun 2016 selanjutnya disebut UU ITE, untuk antisipasi perilaku-perilaku masyarakatnya yang berkaitan dengan kecanggihan teknologi informasi dan digital. Didasarkan pengertian sistem elektronik tersebut, dapat diketahui bahwa yang termasuk ke dalam sistem elektronik adalah "jaringan internet, layanan e-banking, e-government, jejaring sosial, media elektronik, websites, dan lain sebagainya" 1 .

Alinea keempat Pembukaan UUD 1945 menyatakan "negara melindungi segenap bangsa dan seluruh tumpah-darah Indonesia, memajukan kesejahteraan umum, mencerdaskan kehidupan bangsa dan ikut serta melaksanakan ketertiban dunia". Frase negara melindungi segenap bangsa dan seluruh tumpah-darah Indonesia dapat diartikan negara harus membuat suatu sistem pertahanan dan keamanan yang melindungi segenap bangsa dan seluruh tumpah-darah Indonesia.

Pembagian tugas dan wewenang dalam melaksanakan pertahanan dan keamanan negara antara Tentara Nasional Indonesia (TNI) dan Kepolisian Negara Republik Indonesia (POLRI) telah diatur dalam Undang-Undang Dasar 1945. Pasal 30 ayat (3) UUD 1945 menyatakan Tentara Nasional Indonesia terdiri atas Angkatan Darat, Angkatan Laut dan Angkatan Udara sebagai alat Negara bertugas mempertahankan, melindungi, dan memelihara keutuhan dan kedaulatan Negara. Jadi tugas TNI adalah mempertahankan, melindungi, dan memelihara keutuhan dan kedaulatan Negara. Pasal 30 ayat (4) UUD 1945 menyatakan Kepolisian Negara Republik Indonesia sebagai alat Negara yang menjaga keamanan dan ketertiban masyarakat bertugas melindungi, mengayomi, melayani masyarakat, serta menegakkan hukum. Jadi tugas POLRI adalah sebagai alat Negara yang menjaga keamanan dan ketertiban masyarakat bertugas melindungi, mengayomi, melayani masyarakat, serta menegakkan hukum.

Pasal 30 ayat (5) UUD 1945 menyatakan Susunan dan kedudukan Tentara Nasional Indonesia, Kepolisian Negara Republik Indonesia, hubungan kewenanganTentara Nasional Indonesia dan Kepolisian Negara Republik Indonesia di dalam menjalankan tugasnya, syarat-syarat keikutsertaan warga negara, serta hal-hal yang terkait dengan pertahanan dan keamanan diatur dengan undang-undang.

Pasal 30 ayat (5) UUD 1945 mengatur tentang susunan dan kedudukan, hubungan kewenangan TNI dan Polri dalam menjalankan tugas, serta hal-hal lain yang terkait dengan pertahanan dan keamanan, diatur dengan undang-undang .

\footnotetext{
${ }^{1}$ Shidarta, 2000, Hukum Perlindungan Konsumen, Grasindo, Jakarta, hal. 29
} 
Website : http://yustisia.unmermadiun.ac.id/index.php/yustisia

Pasal 12 dan Pasal 13 ayat (1) UU Nomor 3 Tahun 2002 tentangPertahanan Negara, mengatur pengelolaan sistem pertahanan negara untuk melindungi kepentingan nasional dan Presiden berwenang danbertanggung jawab dalam pengelolaan sistem pertahanan Negara.

Pasal 7 ayat (2) dan (3) UU Nomor 3 Tahun 2002 tentang Pertahanan Negara, mengatur sistem Pertahanan Negara dalam menghadapi ancaman militer dan non militer.Untuk menghadapi ancaman militer menempatkan menempatkan Tentara Nasional Indonesia sebagai komponen utama, sedangkan untuk menghadapi menghadapi ancaman non militer menempatkan lembaga pemerintah di luar bidang pertahanan sebagai unsur utama.

Tugas pokok TNI diatur dalam Pasal 7 ayat (1) UU No. 34 tahun 2004 tentang Tentara Nasional Indonesia, menyatakan “ Tugas pokok TNI adalah menegakkan kedaulatan negara, mempertahankan keutuhan wilayah Negara Kesatuan Republik Indonesia yang berdasarkan Pancasila dan Undang-Undang Dasar Negara Republik Indonesia Tahun 1945, serta melindungi segenap bangsa dan seluruh tumpah darah Indonesia dari ancaman dan gangguan terhadap keutuhan bangsa dan Negara".

Makalah ini membahas masalah pertahanan Negara dalam sistem ketatanegaraan Indonesia.

\section{B. Rumusan Masalah}

a. Bagaimanakah pertahanan negara yang dilakukan oleh Tentara Nasional Indonesia dalam Sistem Ketatanegaraan Indonesia.

b. Bagaimanakah hubungan antara Tentara Nasional Indonesia dengan Kepolisian Negara Republik Indonesia melaksanakan Pertahanan Negara dalam Sistem Ketatanegaraan Indonesia.

\section{Tujuan Penelitian}

Tujuan penelitian yaitu ;

a. Untuk mengetahui Pertahanan Negara yang dilakukan oleh TNI dalam sistem Ketatanegaraan Indonesia

b. Untuk mengetahui hubungan antara Tentara Nasional Indonesia dengan Kepolisian Negara Republik Indonesia dalam melaksanakanPertahanan Negara menurut sistem Ketatanegaraan Indonesia.

\section{Manfaat Penelitian}

Manfaat penelitian yaitu :

a. Penelitian ini dapat memberikan sumbangan pemikiran tentang Pertahanan Negara yang dilakukan oleh TNI dalam sistem Ketatanegaraan Indonesia.

b. Penelitian ini dapat menjelaskan hubungan antara Tentara Nasional Indonesia dengan Kepolisian Negara Republik Indonesia dalam melaksanakanPertahanan Negara.

\section{TINJUAN PUSTAKA}

A. Ketetapan Majelis Permusyawaratan Rakyat (MPR) No.VI/MPR/2000 tentang Pemisahan Tentara Nasional Indonesia (TNI) dan Kepolisian Negara Republik Indonesia (Polri) Dan Ketetapan MPR RI No.VII/MPR/2000 tentang Peran Tentara Nasional Indonesia dan Peran Kepolisian Negara Republik Indonesia.

Tap MPR RI No.VI tahun 2000 menegaskan pemisahan TNI dan Polri harus dilakukan oleh negara dan ini merupakan tuntutan reformasisebagai akibat penyimpangan-penyimpangan yang dilakukan oleh kekuatan militer dalam pemerintahan orde baru serta pemisahan tersebut telah sesuai dengan aspirasi masyarakat, hal ini mengingat adanya dwifungsi ABRI yang memberikan kenangan buruk bagi rakyat Indonesia tentang arti dari militeristik yang senantiasa diusung sebagai alat kekuasaan dan bukan sebagai alat negara.

TAP MPR RI No.VI/MPR/2000 tentang Pemisahan Tentara Nasional Indonesia (TNI) dan Kepolisian Negara Republik Indonesia (Polri), menyatakan :

Pasal 1

Tentara Nasional Indonesia dan Kepolisian Negara Republik Indonesia secara kelembagaan terpisah sesuai dengan peran dan fungsi masing-masing.

Pasal 2

1) Tentara Nasional Indonesia adalah alat negara yang berperan dalam pertahanan negara.

2) Kepolisian Negara Republik Indonesia adalah alat negara yang berperan dalam memelihara keamanan.

3) Dalam hal terdapat keterkaitan kegiatan pertahanan dan kegiatan keamanan. Tentara Nasional Indonesia dan Kepolisian Negara Republik Indonesia harus bekerja sama dan saling membantu.

Pasal 3

1) Peran Tentara Nasional Indonesia dan peran Kepolisian Negara Republik Indonesia ditetapkan dengan Ketetapan Majelis Permusyawaratan Rakyat.

2) Hal-hal yang menyangkut Tentara Nasional Indonesia dan Kepolisian Negara Republik Indonesia secara lengkap dan terperinci diatur lebih lanjut dalam undang-undang secara terpisah.

Pasal 4

Ketetapan ini mulai berlaku pada tanggal ditetapkan. 
Selanjutnya Ketetapan MPR RI No.VII/MPR/2000 tentang Peran Tentara Nasional Indonesia dan Peran Kepolisian Negara Republik Indonesia, menyatakan :

BAB I

TENTARA NASIONAL INDONESIA

Pasal 1

Jatidiri Tentara Nasional Indonesia

1) Tentara Nasional Indonesia merupakan bagian dari rakyat, lahir dan berjuang bersama rakyat demi membela kepentingan negara.

2) Tentara Nasional Indonesia berperan sebagai komponen utama dalam sistem pertahanan Negara.

3) Tentara Nasional Indonesia wajib memiliki kemampuan dan keterampilan secara profesional sesuai dengan peran dan fungsinya.

Peran Tentara Nasional Indonesia

Pasal 2

1) Tentara Nasional Indonesia merupakan alat negara yang berperan sebagai alat pertahanan Negara Kesatuan Republik Indonesia.

2) Tentara Nasional Indonesia, sebagai Alat Pertahanan Negara, bertugas pokok menegakkan kedaulatan negara, keutuhan wilayah Negara Kesatuan Republik Indonesia yang berdasarkan Pancasila dan Undang-Undang Dasar 1945, serta melindungi segenap bangsa dan seluruh tumpah darah Indonesia dari ancaman dan gangguan terhadap keutuhan bangsa dan negara.

3) Tentara Nasional Indonesia melaksanakan tugas negara dalam penyelenggaraan wajib militer bagi warga negara yang diatur dengan undang-undang.

Susunan dan Kedudukan Tentara Nasional Indonesia

Pasal 3

1) Tentara Nasional Indonesia terdiri atas Angkatan Darat, Angkatan Laut, dan Angkatan Udara yang organisasinya disusun berdasarkan kebutuhan yang diatur dengan undang-undang.

2) Tentara Nasional Indonesia berada di bawah Presiden.

3) Tentara Nasional Indonesia dipimpin oleh seorang Panglima yang diangkat dan diberhentikan oleh Presiden setelah mendapat persetujuan Dewan Perwakilan Rakyat.

4) a) Prajurit Tentara Nasional Indonesia tunduk kepada kekuasaan peradilan militer dalam hal pelanggaran hukum militer dan tunduk kepada kekuasaan peradilan umum dalam hal pelanggaran hukum pidana umum.

b) Apabila kekuasaan peradilan umum sebagaimana dimaksud pada ayat (4a) pasal ini tidak berfungsi maka prajurit Tentara Nasional Indonesia tunduk di bawah kekuasaan peradilan yang diatur dengan undang-undang.

Pasal 4

Tugas Bantuan Tentara Nasional Indonesia

1) Tentara Nasional Indonesia membantu penyelenggaraan kegiatan kemanusian (civic mission).

2) Tentara Nasional Indonesia memberikan bantuan kepada Kepolisian Negara Republik Indonesia dalam rangka tugas keamanan atas permintaan yang diatur dalam undang-undang.

3) Tentara Nasional Indonesia membantu secara aktif tugas pemeliharan perdamaian dunia (peace keeping operation) di bawah bendera Perserikatan Bangsa-Bangsa.

Pasal 5

Keikutsertaan Tentara Nasional Indonesia Dalam Penyelenggaraan Negara

1) Kebijakan politik negara merupakan dasar kebijakan dan pelaksanan tugas Tentara Nasional Indonesia.

2) Tentara Nasional Indonesia bersikap netral dalam kehidupan politik dan tidak melibatkan diri pada kegiatan politik praktis.

3) Tentara Nasional Indonesia mendukung tegaknya demokrasi, menjunjung tinggi hukum dan hak asasi manusia.

4) Anggota Tentara Nasional Indonesia tidak menggunakan hak memilih dan dipilih. Keikutsertaan Tentara Nasional Indonesia dalam menentukan arah kebijakan nasional disalurkan melalui Majelis Permusyawaratan Rakyat paling lama sampai dengan tahun 2009.

5) Anggota Tentara Nasional Indonesia hanya dapat menduduki jabatan sipil setelah mengundurkan diri atau pensiun dari dinas ketentaraan.

\section{BAB II}

\section{KEPOLISIAN NEGARA REPUBLIK INDONESIA}

Pasal 6

Peran Kepolisian Negara Republik Indonesia

1) Kepolisian Negara Republik Indonesia merupakan alat negara yang berperan dalam memelihara keamanan dan ketertiban masyarakat, menegakkan hukum, memberikan pengayoman, dan pelayanan kepada masyarakat.

2) Dalam menjalankan perannya, Kepolisian Negara Republik Indonesia wajib memiliki keahlian dan keterampilan secara profesional. 
Susunan dan Kedudukan Kepolisian Negara Republik Indonesia

1) Kepolisian Negara Republik Indonesia merupakan Kepolisian Nasional yang organisasinya disusun secara berjenjang dari tingkat pusat sampai tingkat daerah.

2) Kepolisian Negara Republik Indonesia berada di bawah Presiden.

3) Kepolisian Negara Republik Indonesia dipimpin oleh seorang Kepala Kepolisian Negara Republik Indonesia yang diangkat dan diberhentikan oleh Presiden dengan persetujuan Dewan Perwakilan Rakyat.

4) Anggota Kepolisian Negara Republik Indonesia tunduk pada kekuasaan peradilan umum.

$$
\text { Pasal } 8
$$

Lembaga Kepolisian Nasional

1) Presiden dalam menetapkan arah kebijakan Kepolisian Negara Republik Indonesia dibantu oleh lembaga kepolisian nasional.

2) Lembaga kepolisian nasional dibentuk oleh Presiden yang diatur dengan undang-undang.

3) Lembaga kepolisian nasional memberikan pertimbangan kepada Presiden dalam pengangkatan dan pemberhentian Kepala Kepolisian Negara Republik Indonesia.

Tugas Bantuan Kepolisian Negara Republik Indonesia

Pasal 9

1) Dalam keadaan darurat Kepolisian Negara Republik Indonesia memberikan bantuan kepada Tentara Nasional Indonesia, yang diatur dalam undang-undang.

2) Kepolisian Negara Republik Indonesia turut secara aktif dalam tugas-tugas penanggulangan kejahatan internasional sebagai anggota International Criminal Police Organization - Interpol.

3) Kepolisian Negara Republik Indonesia membantu secara aktif tugas pemeliharaan perdamaian dunia (peace keeping operation) di bawah bendera Perserikatan Bangsa-Bangsa.

Pasal 10

Keikutsertaan Kepolisian Negara Republik Indonesia dalam Penyelenggaraan Negara

1) Kepolisian Negara Republik Indonesia bersikap netral dalam kehidupan politik dan tidak melibatkan diri pada kegiatan politik praktis.

2) Anggota Kepolisian Negara Republik Indonesia tidak menggunakan hak memilih dan dipilih. Keikutsertaan Kepolisian Negara Republik Indonesia dalam menentukan arah kebijakan nasional disalurkan melalui Majelis Permusyawaratan Rakyat paling lama sampai dengan tahun 2009.

3) Anggota Kepolisian Negara Republik Indonesia dapat menduduki jabatan di luar kepolisian setelah mengundurkan diri atau pensiun dari dinas kepolisian.

\section{BAB III}

PENUTUP

Pasal 11

Ketentuan sebagaimana dimaksud dalam ketetapan ini diatur lebih lanjut dengan undang-undang.

Pasal 12

Ketetapan ini mulai berlaku pada tanggal ditetapkan.

\section{B. Pertahanan Negara}

Kata pertahanan berasal dari kata dasar tahan.Dalam kamus besar bahasa Indonesia, kata tahan mempunyai arti keadaan tetap meskipun mengalami berbagai hal Dengan pengertian tersebut, pertahanan merupakan suatu upaya yang dilakukan untuk menciptakan kondisi atau keadaan yang stabil

Pasal 1 ayat (1) UU No. 3 Tahun 2002 tentang Pertahanan Negara, mendefinisikan Pertahanan negara adalah segala usaha untuk mempertahankan kedaulatan negara, keutuhan wilayah Negara Kesatuan Republik Indonesia, dan keselamatan segenap bangsa dari ancaman dan gangguan terhadap keutuhan bangsa dan Negara.

Pertahanan Negara merupakan salah satu unsur sistem keamanan nasional. Pertahanan Negara dilakukan untuk menghadapi dan mengatasi serangan fisik militer yang dilakukan Negara lain terhadap Indonesia. Dengan menyerang Indonesia menggunakan kekuatan militer, Negara tersebut melakukan perang terhadap Indonesia (Sayidiman Suryohadiprojo, 2005:8).

\section{Komponen Pertahanan Negara}

Komponen pertahanan Negara diatur dalam Pasal 1 ayat 5,6 dan 7 UU No. 3 Tahun 2002 tentang Pertahanan Negara, terdiri komponen utama, komponen cadangan dan komponen pendukunng. Komponen utama adalah Tentara Nasional Indonesia yang siap digunakan untuk melaksanakan tugas-tugas pertahanan. Komponen cadangan adalah sumber daya nasional yang telah disiapkan untuk dikerahkan melalui mobilisasi guna memperbesar dan memperkuat kekuatan dan kemampuan komponen utama. Komponen pendukung adalah sumber daya nasional yang dapat digunakan untuk meningkatkan kekuatan dan kemampuan komponen utama dan komponen cadangan.

Selanjutnya Pasal 8 ayat 1 dan 2 UU No. 3 Tahun 2002 tentang Pertahanan Negara, menyebutkan yaitu : komponen cadangan, terdiri atas warga negara, sumber daya alam, sumber daya buatan, serta sarana dan prasarana nasional yang telah 
Website : http://yustisia.unmermadiun.ac.id/index.php/yustisia

disiapkan untuk dikerahkan melalui mobilisasi guna memperbesar dan memperkuat komponen utama dan komponen pendukung, terdiri atas warga negara, sumber daya alam, sumberdaya buatan, serta sarana dan prasarana nasional yang secara langsung atau tidak langsung dapat meningkatkan kekuatan dan kemampuan komponen utama dan komponen cadangan.

\section{Kekuasaan Presiden Dalam Pertahanan Negara}

Kekuasaan Presisiden dalam pertahanan Negara diatur dalam Pasal 10 UUD 1945 yaitu "Presiden memegang kekuasaan yang tertinggi atas Angkatan Darat, Angkatan Laut dan Angkatan Udara”. Selanjutnya dalam Pasal 30 menyatakan :

1) Tiap-tiap warga negara berhak dan wajib ikut serta dalam usaha pertahanan dan keamanan negara.

2) Usaha pertahanan dan keamanan negara dilaksanakan melalui sistem pertahanan dan keamanan rakyat semesta oleh Tentara Nasional Indonesia dan Kepolisian Negara Republik Indonesia, sebagai kekuatan utama, dan rakyat sebagai kekuatan pendukung.

3) Tentara Nasional Indonesia terdiri atas Angkatan Darat, Angkatan Laut, dan Angkatan Udara sebagai alat negara bertugas mempertahankan, melindungi, dan memelihara keutuhan dan kedaulatan negara.

4) Kepolisian Negara Republik Indonesia sebagai alat negara yang menjaga keamanan dan ketertiban masyarakat bertugas melindungi, mengayomi, melayani masyarakat, serta menegakkan hukum.

5) Susunan dan kedudukan Tentara Nasional Indonesia, Kepolisian Negara Republik Indonesia, hubungan kewenangan Tentara Nasional Indonesia dan Kepolisian Negara Republik Indonesia di dalam menjalankan tugasnya, syarat-syarat keikutsertaan warga negara dalam usaha pertahanan dan keamanan negara, serta hal-hal yang terkait dengan pertahanan dan keamanan diatur dengan undang-undang.

\section{III.METODE PENELITIAN}

Penelitian merupakan sarana pokok dalam pengembangan ilmu pengetahuan maupun teknologi.Hal ini disebabkan, oleh karena penelitian bertujuan untukmengungkapkan kebenaran secara sistematis, metodologi, dan konsisten. Melaluiproses penelitian tersebut diadakan analisa dan konstruksi terhadap data yang telahdikumpulkan dan diolah. (Soerjono Soekanto, 1990:1)

A. Tipe penelitian

Penelitian ini adalah penelitian hukum normatif, karena memakai data sekunder (bahan pustaka). Penelitian hukum normatif adalah penelitian hukum yang dilakukan dengan cara meneliti bahan pustaka atau data sekunder belaka.(Soerjono Soekamto dan Sri Mamudji, 2004:13).

B. Metode Pendekatan

Menggunakan dua macam pendekatan, yakni pendekatan perundang-undangan (statute approach) dan pendekatan asas-asas hukum (legal principle approach).

C. Metode Pengumpulan Data

Pengumpulan data dalam penelitian ini menggunakan studi pustaka, dokumen dan arsip

D. Sumber Data

Penelitian ini memakai sumber data sekunder, yang terdiri dari :

a. Non Bahan seperti arsip, dokumen.

b. Bahan hukum, terdiri dari :

1) Primer, seperti peraturan perundang-undangan

2) Sekunder, seperti buku-buku, jurnal

3) Tertier, seperti kamus.

E. Teknik Analisa Data

Analisis data adalah proses mengatur urutann data mengorganisasikannya ke dalam suatu pola, kategori dan satuan uraian dasar.(Lexy J. leong, 1990:3)

Penelitian ini memakai analisis deskriptif kualitatif dengan cara menguraikan, menjabarkan, dan menjelaskan konsep dan teori.

\section{IV.PEMBAHASAN HASILPENELITIAN}

\section{A. Tugas pertahanan Negara yang dilakukan oleh TNI dalam sistem Ketatanegaraan Indonesia.}

\section{Kedudukan TNI}

Kedudukan TNI dibawah Presiden, dasar hukumnya yaitu :

a. Pasal 10 UUD 1945 yaitu "Presiden memegang kekuasaan yang tertinggi atas Angkatan Darat, Angkatan Laut dan Angkatan Udara".

b. Pasal 3 ayat (2) TAP MPR RI No.VII/MPR/2000 tentang Peran Tentara Nasional Indonesia dan Peran Kepolisian Negara Republik Indonesia, menyatakan "Tentara Nasional Indonesia berada di bawah Presiden".

c. Pasal 3 ayat (1) UU No.3 Tahun 2002 tentang Tentara Nasional Indonesia, menyatakan "Dalam pengerahan dan penggunaan kekuatan militer, TNI berkedudukan di bawah Presiden". 
Dengan demikian kedudukan Panglima TNI dan Menteri Pertahanan dibawah Presiden. Adapun tugas dan tanggung jawab Panglima TNI, diatur Pasal 15 UU No. 34 Tahun 2004 tentang Tentara Nasional Indonesia, yatu :

a. memimpin TNI;

b. melaksanakan kebijakan pertahanan negara;

c. menyelenggarakan strategi militer dan melaksanakan operasi militer;

d. mengembangkan doktrin TNI;

e. menyelenggarakan penggunaan kekuatan TNI bagi kepentingan operasi militer;

f. menyelenggarakan pembinaan kekuatan TNI sertamemelihara kesiagaan operasional;

g. memberikan pertimbangan kepada MenteriPertahanan dalam hal penetapan kebijakan pertahanan negara;

h. Memberikanpertimbangan kepada Menteri Pertahanan dalam hal penetapan kebijakan pemenuhankebutuhan TNI dan komponen pertahanan lainnya;

i. memberikan pertimbangankepada Menteri Pertahanan dalam menyusun dan melaksanakan perencanaan strategispengelolaan sumber daya nasional untuk kepentingan pertahanan negara;

j. menggunakan komponen cadangan setelah dimobilisasi bagi kepentingan operasimiliter;

k. menggunakan komponen pendukung yang telah disiapkan bagikepentingan operasi militer; serta

1. melaksanakan tugas dan kewajiban lain sesuaidengan peraturan perundang-undangan.

Kewenangan dan tanggung jawab Menteri Pertahanan diatur Pasal16 UU No.3 Tahun 2002 tentang Pertahanan Negara, yaitu :

a. membantu Presiden dalam merumuskan kebijakan umum pertahanan negara.

b. menetapkan kebijakan tentang penyelenggaraan pertahanan negara berdasarkan kebijakan umum yang ditetapkan Presiden.

c. menyusun buku putih pertahanan serta menetapkan kebijakan kerja sama bilateral, regional, dan internasional di bidangnya.

d. merumuskan kebijakan umum penggunaan kekuatan Tentara Nasional Indonesia dan komponen pertahanan lainnya.

e. menetapkan kebijakan penganggaran, pengadaan, perekrutan, pengelolaan sumber daya nasional, serta pembinaan teknologi dan industri pertahanan yang diperlukan oleh Tentara Nasional Indonesia dan komponen kekuatan pertahanan lainnya.

\section{Penyelenggara Pertahanan Negara}

Dasar hukum penyelenggaraan Pertahanan Negara Indonesia yang dilakukan TNI, yaitu :

a) Pasal 30 Ayat (2) dan (3) UUD 1945, menyatakan:

(2) Usaha pertahanan dan keamanan negara dilaksanakan melalui sistem pertahanan dan keamanan rakyat semesta oleh TentaraNasional Indonesia dan Kepolisian Republik Indonesia sebagai kekuatan utama, danrakyat sebagai pendukung.

(3) Tentara Nasional Indonesia terdiri atas Angkatan Darat, Angkatan Laut, dan Angkatan Udara sebagai alat negara bertugas mempertahankan, melindungi, dan memelihara keutuhan dan kedaulatan negara".

(b). Pasal 5 UU No. 34 Tahun 2004 tentang Tentara Nasional Indonesia, menyatakan "TNI berperan sebagai alat negara di bidang pertahanan yang dalam menjalankan tugasnya berdasarkan kebijakan dan keputusan politik Negara".

(c). Pasal 6 ayat (1) dan (2) UU No. 34 Tahun 2004 tentang Tentara Nasional Indonesia, mengatur TNI, sebagai alat pertahanan negara, berfungsi sebagai :

(1) TNI sebagai alat pertahanan negara berfungsi sebagai:

a. penangkal terhadap setiap bentuk ancaman militer dan ancaman bersenjata dari luar dan dalam negeri terhadap kedaulatan, keutuhan wilayah, dan keselamatan bangsa;

b. penindak terhadap setiap bentuk ancaman sebagaimana dimaksud pada Ayat (1) huruf a; dan

c. pemulih terhadap kondisi keamanan negara yang terganggu akibat kekacauan keamanan.

(2) Dalam melaksanakan fungsi sebagaimana dimaksud pada ayat (1), TNI merupakan komponen utama sistem pertahanan Negara.

\section{Tugas Pokok TNI}

Tugas pokok TNI diatur dalam Pasal 7 ayat (1) UU No. 34 tahun 2004 tentang Tentara Nasional Indonesia, menyatakan “ Tugas pokok TNI adalah menegakkan kedaulatan negara, mempertahankan keutuhan wilayah Negara Kesatuan Republik Indonesia yang berdasarkan Pancasila dan Undang-Undang Dasar Negara Republik Indonesia Tahun 1945, serta melindungi segenap bangsa dan seluruh tumpah darah Indonesia dari ancaman dan gangguan terhadap keutuhan bangsa dan Negara".

Selanjutnya Pasal 7 ayat 2 UU No. 34 tahun 2004 tentang Tentara Nasional Indonesia menyatakan "Tugas pokok sebagaimana dimaksud pada ayat (1) dilakukan dengan :

a. Operasi militer untuk perang.

b. Operasi militer selain perang yaitu untuk : 
Website : http://yustisia.unmermadiun.ac.id/index.php/yustisia

1. mengatasi gerakan separatisme bersenjata;

2. mengatasi pemberontakan bersenjata;

3. mengatasi aksi terorisme;

4. mengamankan wilayah perbatasan;

5. mengamankan objek vital nasional yang bersifat strategis

6. melaksanakan tugas perdamaian dunia sesuai dengan kebijakan politik luar negeri;

7. mengamankan Presiden dan Wakil Presiden beserta keluarganya

8. memberdayakan wilayah pertahanan dan kekuatan pendukungnya secara dini sesuai dengan sistem pertahanan semesta;

9. membantu tugas pemerintahan di daerah;

10. membantu Kepolisian Negara Republik Indonesia dalam rangka tugas keamanan dan ketertiban masyarakat yang diatur dalam undang-undang;

11. membantu mengamankan tamu negara setingkat kepala negara dan perwakilan pemerintah asing yang sedang berada di Indonesia;

12. membantu mengamankan tamu negara setingkat kepala negara dan perwakilan pemerintah asing yang sedang berada di Indonesia;

13. membantu pencarian dan pertolongan dalam kecelakaan (search and rescue); serta;

14. membantu pemerintah dalam pengamanan pelayaran dan penerbangan terhadap pembajakan, perompakan, dan penyelundupan.

Menurut Jimly Assiddiqie (2008:251), Tugas pokok yang dimaksud pada Ayat (1) tersebut dilakukan dengan atau melalui: (a) operasi militer untuk perang; dan (b) operasi militer selain perang. Hal yang dimaksud dengan operasi militer untuk perang adalah segala bentuk pengerahan dan penggunaan kekuasaan tentara untuk melawan kekuatan militer negara lain yang melakukan agresi terhadap Indonesia dan/atau dalam konflik bersenjata dengan suatu negara lain atau lebih yang didahului oleh adanya deklarasi pernyataan perang dan tunduk pada ketentuan hukum perang Internasional.

Ancaman dan gangguan terhadap keutuhan bangsa dan negara, antara lain :

1) Agresi berupa penggunaan kekuatan bersenjata oleh negara lain terhadapkedaulatan negara, keutuhan wilayah, dan keselamatan segenap bangsa atau dalambentuk dan cara-cara, antara lain:

a) invasi berupa penggunaan kekuatan bersenjata;

b) bombardemen berupa penggunaan senjata lainnya;

c) blokade pelabuhan, pantai, wilayah udara, atau seluruh wilayah NegaraKesatuan Republik Indonesia;

d) serangan bersenjata negara lain terhadap unsur satuan darat, laut. dan udara;

e) Keberadaan atau tindakan unsur kekuatan bersenjata asing dalam wilayah NKRI yang bertentangan dengan ketentuan atau perjanjian yang telahdisepakati;

f) Tindakan suatu negara yang mengizinkan penggunaan wilayahnya oleh Negara lain untuk melakukan agresi atau invasi terhadap NKRI:

g) Pengiriman kelompok bersenjata atau tentara bayaran untuk melakukantindakan kekerasan di wilayah NKRI;

h) Ancaman lain yang ditetapkan oleh Presiden.

2) Pelanggaran wilayah yang dilakukan oleh negara lain;

3) Pemberontakan bersenjata, yaitu suatu gerakan bersenjata yang melawan pemerintah yang sah;

4) Sabotase dan pihak tertentu untuk merusak instalasi penting dan objek vital nasional;

5) Spionase yang dilakukan oleh negara lain untuk mencari dan mendapatkan rahasiamiliter;

6) Aksi teror bersenjata yang dilakukan oleh teroris internasional atau bekerja samadengan teroris dalam negeri atau oleh teroris dalam negeri;

7) Ancaman keamanan di laut atau udara yurisdiksi nasional Indonesia, yangdilakukan pihak-pihak tertentu, dapat berupa:

a) pembajakan atau perompakan;

b) penyelundupan senjata, amunisi, dan bahan peledak atau bahan lain yangdapat membahayakan keselamatan bangsa;

c) penangkapan ikan secara ilegal atau pencurian kekayaan laut.

8) Konflik komunal yang terjadi antar kelompok masyarakat yang dapatmembahayakan keselamatan bangsa.

\section{Pengerahan Dan Penggunaan kekuatan TNI}

Pasal 3 ayat (1) UU No. 34 Tahun 2004 tentang Tentara Nasional Indonesia menyatakan "Dalam pengerahan dan penggunaan kekuatan militer, TNI berkedudukan di bawah Presiden".

Selanjutnya dalam Pengerahan dan penggunaan kekuatan militer (TNI) diatur pada Pasal 17 dan 18 UU No. 34 Tahun 2004 tentang Tentara Nasional Indonesia sebagai berikut :

Pasal 17

1) Kewenangan dan tanggung jawab pengerahan kekuatan TNI berada pada Presiden 
Website : http://yustisia.unmermadiun.ac.id/index.php/yustisia

2) Dalam hal pengerahan kekuatan TNI sebagaimana dimaksud pada ayat (1), Presiden harus mendapat persetujuan Dewan Perwakilan Rakyat.

Pasal 18

1) Dalam keadaan memaksa untuk menghadapi ancaman militer dan/atau ancaman bersenjata, Presiden dapat langsung mengerahkan kekuatan TNI

2) Dalam hal pengerahan langsung kekuatan TNI sebagimana dimaksud pada ayat (1), dalam waktu 2 X 24 jam terhitung sejak dikeluarkannya keputusan pengerahan kekuatan, Presiden harus melaporkan kepada Dewan Perwakilan Rakyat.

3) Dalam hal Dewan Perwakilan Rakyat tidak menyetujui pengerahan sebagaimana dimaksud pada ayat (1) dan ayat (2), Presiden harus menghentikan pengerahan kekuatan TNI tersebut.

\section{B. Hubungan antara Tentara Nasional Indonesia dengan Kepolisian Negara Republik Indonesia dalam melaksanakan Pertahanan.}

\section{Tugas Tentara Nasional Indonesia dalam Operasi Militer selain Perang}

Pasal 7 Ayat (2) huruf b UU No. 34 Tahun 2004 tentang Tentara Nasional Indonesia, ditentukan operasi-operasi militer selain perang, yaitu :

a) mengatasi gerakan separatisme bersenjata:

b) mengatasi pemberontakan bersenjata;

c) mengatasi aksi terorisme;

d) mengamankan wilayah perbatasan;

e) mengamankan objek vital nasional yang bersifat strategis;

f) melaksanakan tugas perdamaian dunia sesuai dengan kebijakan politik luar negeri;

g) mengamankan Presiden dan Wakil Presiden beserta keluarganya;

h) memberdayakan wilayah pertahanan dan kekuatan pendukungnya secara dini sesuai dengan sistem pertahanan semesta;

i) membantu tugas pemerintahan di daerah;

j) membantu Kepolisian Negara Republik Indonesia dalam rangka tugas keamanandan ketertiban masyarakat yang diatur dalam undangundang;

k) membantu mengamankan tamu negara setingkat kepala dan perwakilanpemerintah asing yang sedang berada di Indonesia;

1) membantu menanggulangi akibat bencana alam, pengungsian, dan pemberian bantuan kemanusiaan;

m) membantu pencarian dan pertolongan dalam kecelakaan (search and rescue);serta

n) membantu pemerintah dalam pengamanan pelayaran dan penerbangan terhadap pembajakan, perompakan, dan penyeludupan.

Pelaksanaan tugas-tugas tersebut di atas, baik tugas operasi perang maupun tugas operasi nonperang yang terdiri atas keempat belas macam tugas operasi, dijalankan TNI atas dasar kebijakan dan keputusan politik Negara.

Untuk melaksanakan tugas-tugas tersebut, baik dalam rangka perang maupun non perang, TNI tidak dapat mengambil inisiatif sendiri tanpa adanya keputusan politik dari otoritas sipil.

Empat belas jenis tugas nonperang tersebut, dapat dibedakan dalam keadaan-keadaan yang berbeda.Ada tugas operasi yang dilakukan dalam keadaan darurat militer, ada tugas-tugas dalam keadaan darurat sipil, dan ada pula tugas yang dilakukan dalam semua keadaan, termasuk keadaan normal atau tertib sipil. Misalnya, tugas-tugas nomor 4 sampai dengan nomor 11 dapat dilakukan sebagai tugas rutin dalam kondisi damai atau keadaan tertib sipil, yaitu:

a) mengamankan wilayah perbatasan;

b) mengamankan objek vital nasional yang bersifat strategis;

c) melaksanakan tugas perdamaian dunia sesuai dengan kebijakan politik luar negeri;

d) mengamankan Presiden dan Wakil Presiden beserta keluarganya;

e) memberdayakan wilayah pertahanan dan kekuatan pendukungnva secara dini sesuai dengan sistem pertahanan semesta;

f) membantu tugas pemerintahan di daerah:

g) membantu Kepolisian Negara Republik Indonesia dalam rangka tugas keamanan dan ketertiban masyarakat yang diatur dalam undang-undang;

h) membantu mengamankan tamu negara setingkat kepala dan perwakilan pemerintah asing yang sedang berada di Indonesia;

i) membantu menanggulangi akibat bencana alam, pengungsian, dan pemberianbantuan kemanusiaan;

j) membantu pencarian dan pertolongan dalam kecelakaan (search and rescue); serta

k) membantu pemerintah dalam pengamanan pelayaran dan penerbangan terhadap pembajakan, perompakan, dan penyelundupan.

Untuk tugas nomor 1 sampai dengan nomor 3 dapat terjadi dalam keadaan darurat militer, yaitu : 
a) mengatasi gerakan separatisme bersenjata;

b) mengatasi pemberontakan bersenjata;

c) mengatasi aksi terorisme;

Pasal 5 UU No. 34 Tahun 2004 tentang TNI, menyatakan TNI berperan sebagai alat negara di bidang pertahanan yang dalam menjalankan tugasnya berdasarkan kebijakan dan keputusan politik Negara.

Penjelasan pasal Pasal 5 UU No. 34 Tahun 2004 tentang TNI, menyatakan : Yang dimaksud dengan kebijakan dan keputusan politik negara adalah kebijakan politik pemerintah bersama-sama Dewan Perwakilan Rakyat yang dirumuskan melalui mekanisme hubungan kerja antara pemerintah dan Dewan Perwakilan Rakyat, seperti rapat konsultasi dan rapat kerja sesuai dengan peraturan perundang-undangan.

Tentara Nasional Indonesia melaksanakan keputusan politik yang dibuat oleh otoritas sipil, tidak ikut terlibat dalam pengambilan keputusan politik.

Tugas operasi selain perang yang dilakukan Tentara Nasional Inodonesiauntuk membantu Kepolisian Negara Republik Indonesia dalam rangka tugas keamanan dan ketertiban masyarakat.

2. Hubungan tugas Tentara Nasional Indonesia dengan Kepolisian Negara Republik Indonesia dalam Pertahanan dan Keamanan Negara.

UUD 1945 Bab XII tentang Pertahanandan Keamanan Negara Pasal 30 mengatur tentang usaha pertahanandan keamanan negara, sistem pertahanan dan keamanan negara, dan lembaga yang mengatur fungsi di bidang pertahanan dan keamanan Negara.

Bab XII Pasal 30 UUD 1945 menyatakan :

a) Tiap-tiap warga negara berhak dan wajib ikut serta dalam usaha pertahanan dankeamanan negara.

b) Usaha pertahanan dan keamanan negara dilaksanakan melalui sistem pertahanan dan keamanan rakyat semesta oleh Tentara Nasional dan Kepolisian Negara Republik Indonesia, sebagai kekuatan utama, dan rakyat, sebagai kekuatan pendukung.

c) Tentara Nasional Indonesia terdiri atas Angkatan Darat, Angkatan Laut, dan Angkatan Udara sebagai alat negara bertugas mempertahankan, melindungi, dan memelihara keutuhan dan kedaulatan negara.

d) Kepolisian Negara Republik Indonesia sebagai alat negara yang menjaga keamanan dan ketertiban masyarakat bertugas melindungi, mengayomi, melarani masyarakat, serta menegakkan hukum.

e) Susunan data kedudukan Tentara Nasional Indonesia, kepolisian Negara Republik Indonesia, hubungan kewenangan Tentara Nasional Indonesia dan Kepolisian Negara Republik Indonesia di dalam menjalankan tugasnya, syarat-syarat keikutsertaan warga negara dalam usaha pertahanan dan keamanan negara, serta hal-hal yang terkait dengan pertahanan dan keamanan diatur dengan undang-undang.

Secara substansial, rumusan Pasal 30 UUD 1945 membedakan pertahanan Negara dan keamanan Negara.

Pertahanan Negara adalahfungsi untuk menjaga keutuhan negara, kedaulatan negara, dan keselamatan Negara, sedangkan keamanan adalah fungsi untuk memelihara ketertiban, dan penegakan hukum. Walaupun dibedakan, tetapi fungsi pertahanan dan keamanan negara tidak dapat dipisahkan.Keadaan pertahanan negara ditentukan oleh keamanan negara, begitu sebaliknya sebaliknya.Karena itu, meskipun kedua fungsi tersebut dipisahkan dan diemban oleh lembaga yang berbeda, tetap harus ada hubungan dan mekanisme koordinasi bersama.

Ketentuan Pasal 30 ayat (1) UUD 1945 dihubungkan Pasal 30 ayat (2) UUD 1945 tentang sistem pertahanan dan keamanan rakyat semesta yang dilaksanakan oleh Tentara Nasional Indonesia dan Kepolisian Negara Republik Indonesia sebagai kekuatan utama dan rakyat sebagai kekuatan pendukung.

Pelaksanaan sistem pertahanan dan keamanan rakyat semesta harus jelas tentang peran dari Tentara Nasional Indonesia dan Kepolisian Negara Republik Indonesia sebagai kekuatan utama dan rakyat sebagai kekuatan pendukung sesuai jenis dan derajat ancaman terhadap pertahanan dan keamanan negara.

Selanjutnya Pasal 30 UUD 1945 khususnya ayat (3) dan (4) yang menegaskan Tentara Nasional Indonesia sebagai alat negara yang bertugas mempertahankan, melindungi, dan memelihara keutuhan dan kedaulatan negara, serta Kepolisian Negara Republik Indonesia sebagai alat negara yang menjaga keamanan dan ketertiban masyarakat yang bertugas melindungi, mengayomi, melayani masyarakat, serta menegakkan hukum. Ketentuan tersebut merupakan penegasan adanya pembagian tugas antara Tentara Nasional Indonesia di bidang pertahanan dan Kepolisian Negara Republik Indonesia di bidang keamanan.

Bidang pertahanan tugasnya menjaga keutuhan negara, kedaulatan negara, dan keselamatan negara.Sedangkan bidang keamanan tugasnya melindungi, mengayomi, dan melayani masyarakat demi terwujudnva keamanan dan ketertiban, serta fungsi penegakan hukum.Adanya Pembagian tugas ini diharapkan meningkatkan profesionalismeTentara Nasional Indonesia dan Kepolisian Negara Republik Indonesia karena tidak lagi masuk pada wilayah politik sebagaimana pada masa Orde Baru yang membuat Tentara Nasional Indonesia dan Kepolisian Negara Republik Indonesia lebih sebagai alat politik sehingga kehilangan profesionalismenya. 


\section{PENUTUP}

\section{A. Kesimpulan}

1. Tugas pokok TNI diatur dalam Pasal 7 ayat (1) UU No. 34 tahun 2004 tentang Tentara Nasional Indonesia, menyatakan “ Tugas pokok TNI adalah menegakkan kedaulatan negara, mempertahankan keutuhan wilayah Negara Kesatuan Republik Indonesia yang berdasarkan Pancasila dan Undang-Undang Dasar Negara Republik Indonesia Tahun 1945, serta melindungi segenap bangsa dan seluruh tumpah darah Indonesia dari ancaman dan gangguan terhadap keutuhan bangsa dan Negara.

2. Hubungan antara Tentara Nasional Indonesia dengan Kepolisian Negara Republik Indonesia melaksanakan Pertahanan Negara dalam Sistem Ketatanegaraan Indonesia yaitu :

a. Tugas operasi selain perang yang dilakukan Tentara Nasional Inodonesia untuk membantu Kepolisian Negara Republik Indonesia dalam rangka tugas keamanan dan ketertiban masyarakat

b. Bidang pertahanan yang menjadi tugas Tentara Nasional Indonesia dan bidang keamanan yang menjadi tugas Kepolisian Negara Republik Indonesia tidak dapat dipisahkan.

\section{B. Saran-saran}

1. Karena dalam peraturan perungdang-undangan sudah diatur secara jelas tugas Tentara Nasionnal Indonesia dan Kepolisian Negara Republik Indonesia, maka lebih ditingkatkan profesionalisme Tentara Nasional Indonesia dan Kepolisian Negara Republik Indonesia.

2. Tentara Nasional Indonesia dan Kepolisian Negara Republik Indonesia terus bersinergi untuk membantu Kepolisian Negara Republik Indonesia dalam rangka tugas keamanan dan ketertiban masyarakat.

\section{VI.DAFTAR PUSTAKA}

\section{A. Buku}

Abu Bakar Munir, Siti hajat Mohd Yasin \& Md. Ershadul Karim, 2017, Data Protection Law in Asia Sweet \& Maxwell. Burhan D. Magenda, Militer dan Politik, PT. Rajawali, Jakarta, 1998.

Jimly Assiddiqie, Hukum Tata Negara Darurat. Jakarta : Raja Grafindo Persada, 2008.

Muhadjir Effendy, Profesionalime Militer Profesionalisme TNI,UMM Press, Malang,2008.

Salim Said, Tumbuh dan Tumbangnya Dwifungsi: Perkembangan Pemikiran Politik MiliterIndonesia, Aksara Kurnia, Jakarta, 2002.

Sayidiman Suryohadiprojo,Sivis Pacem Para Bellum, Membangun Pertahanan Negarayang Modern dan Efektif, Jakarta : PT Gramedia Pustaka Utama, 2005.

Sulistyo, Hermawan (et al),Keamanan Negara, Keamanan Nasional dan CivilSociety. Jakarta : Pencil, 2009.

Soerjono Soekanto, Penelitian Hukum Normatif. Jakarta: Rajawali Press, 1990.

Soejono Soekamto dan Sri Mamudji, Penelitian Hukum Normatif Suatu Tinjauan Singkat, Grafindo Persada, Jakarta, 2004.

\section{B. Peraturan Perundang-undangan}

Indonesia, Undang-Undang Dasar Negara Republik Indonesia 1945.

Undang - Undang Nomor 34 Tahun 2004 Tentang Tentara Nasional Indonesia.

........., Undang - Undang Nomor 3 tahun 2002 Tentang Pertahanan Negara.
........, Undang - Undang Nomor 2 Tahun 2002 Tentang Kepolisian Negara Republik Indonesia 